\title{
Developing guided inquiry module in animal reproductive system material
}

\author{
Nosi Qadariah a,1, Sri Rahayu Lestari a,2, , Fatchur Rohman a,3 \\ a Department of Biology, Faculty of Mathematics and Natural Sciences, Universitas Negeri Malang, J Semarang No.5 Malang 65145 , \\ East Java, Indonesia \\ ${ }^{1}$ nosiqadariah1201355@gmail.com; ${ }^{2}$ srirahayulestari@um.ac.id* ; ${ }^{3}$ fatchur.rohman.fmipa@um.ac.id \\ * Corresponding author
}

\begin{tabular}{|c|c|}
\hline ARTICLE INFO & ABSTRACT \\
\hline $\begin{array}{l}\text { Article history } \\
\text { Received May 15, } 2020 \\
\text { Revised June 8, } 2020 \\
\text { Accepted June 17, } 2020 \\
\text { Published July 21, } 2020 \\
\text { Keywords } \\
\text { Animal reproductive system } \\
\text { Cognitive learning outcomes } \\
\text { Guided inquiry module } \\
\text { Science process skills }\end{array}$ & $\begin{array}{l}\text { Guided inquiry module is one of alternative to improve students' science process skills } \\
\text { and cognitive learning outcomes. The aim of this research was to produce guided } \\
\text { inquiry module in animal reproductive system material as well as improving student } \\
\text { science process skills and cognitive learning outcomes. The research used ADDIE } \\
\text { development model which consists of the following stages: analyze, design, develop, } \\
\text { implement, and evaluation. The research instruments for collecting the data included } \\
\text { material and media expert validation sheets, field practitioner questionnaire, module } \\
\text { practicality questionnaire, pretest and posttest question sheets (used to measure } \\
\text { science process skills and cognitive learning outcomes). The data analysis technique } \\
\text { used were quantitative and qualitative descriptions as well as quade's rank analysis of } \\
\text { covariance. The results of content and media expert validations were } 94.84 \% \text { and } \\
92.43 \% \text { respectively. In addition, the field practitioner response reached } 95.7 \% \text { and the } \\
\text { module practicality value was } 91.3 \% \text {. Furthermore, the module has significantly } \\
\text { improved students' science process skills }[\mathrm{F}(1,78)=42.509, p<0.05] \text { and cognitive } \\
\text { learning outcome [ } F(1,78)=7.480, p<0.05] \text {. Hence, the module is recommended to } \\
\text { be implemented in delivering animal reproductive system. }\end{array}$ \\
\hline
\end{tabular}

How to cite: Qadariah, N., Lestari, S.R., \& Rohman, F. (2020). Developing guided inquiry module in animal reproductive system material. JPBI (Jurnal Pendidikan Biologi Indonesia), 6(2), 305-316. doi: https://doi.org/10.22219/jpbi.v6i2.12207

\section{INTRODUCTION}

Science process skills in the $21^{\text {st }}$ century are abilities that can be transferred widely, involving scientific disciplines, and reflect scientific behavior, which emphasizes the learning process used to investigate and develop scientific concepts, be able to solve problems, make decisions, find answers, and have a scientific attitude (Ekici \& Erdem, 2020). A learning method in IKIP Budi Utomo Malang Animal Physiology Semester Learning Plan used to develop science process skills in animal physiology courses should be conducted with a combination of small group discussion, class demonstration, independent assignment, and laboratory practice. Needs analysis questionnaire and interview with lecturers on May 24, 2018, suggests that the 
learning process has not integrated science process skills, the general learning is conducted using presentation and discussion. This type of lecture causes low student cognitive learning outcomes.

The cognitive learning outcome associates with student understanding, reasoning, and intellectual level on content studied (Bloom, Engelhart, Furst, Hill, \& Krathwohl, 1956). The low student cognitive learning outcome is evidenced by a formative test value of 49.25 , which is very low. Observation is also conducted on content in animal physiology course. The result of observation on lecturer and students indicates that the difficult topic is the reproduction system. The difficulty is related to the content that is abstract and complex (25\% students), a concept taught is a comprehension (20.8\% students), it is hard to apply in real life (12.5\% students), and less availability of teaching materials that are relevant and applicable in real life (37.5\% students). The main cause of difficulty in learning is less availability of teaching materials in reproduction system content.

Reproduction system content requires students to understand the reproduction system's anatomy structure, connect the reproduction organ structure and function, and explain various mechanisms that occurred in the reproduction system (Seeley, Tate, \& Stephens, 2008). An active and creative contextual learning is thus required that involves students to find knowledge, collect data, test hypotheses, find new understanding, conduct skill practice, and obtain knowledge based on learning experiences (Buck, Latta, \& Pelecky, 2007). The appropriate learning model is a guided inquiry equipped with research results. One of the basic efforts to apply the research results in the learning process is through laboratory practice methods (Llewellyn, 2013).

Animal physiology learning in IKIP Budi Utomo Malang has not implemented a laboratory practice method. The most reasonable laboratory practice in reproduction system content to be conducted in IKIP Budi Utomo Malang is sperm observation. The phenomenon that occurred in daily life in a community is the discovery of many hyperlipidemia conditions. Hyperlipidemia has an impact on the decrease in sperm quality. Single clove garlic (Allium sativum) is one of the natural ingredients that could reduce hyperlipidemia; thus, it could improve sperm quality. Mice are used as a model animal in the hyperlipidemia research (Qadariah, Lestari, \& Rohman, 2020).

The learning approach based on research results is expected to help students comprehend between theoretical studies available in teaching materials and the reality of the research results (Newton \& Tonelli, 2020; Pambudiono, Suarsini, \& Amin, 2016). Learning using a guided inquiry model that contains research results requires teaching sources. The observation results indicate that lecturer and $97 \%$ of students choose the module. The lecturer choose the module since it is one of the learning sources to facilitate teaching, whereas students choose it because it could be an interesting and good learning guide, it uses a learning model, it improves understanding and interest to study, and it could be used independently as well as with lecturer guidance. The module could load a guided inquiry model syntax; thus, it could be used as a learning source. The guided inquiry learning model can improve science process skills (Ekici \& Erdem, 2020; Graaf, Segers, \& Jong, 2020) and cognitive learning outcomes (Cho, Kim, \& Choi, 2017; Donohoe, 2019).

The guided inquiry module based on the research results could teach students to find knowledge independently through experiments, observations, and deepening concepts. A module that contains a research result could provide new information for students (Parmin \& Peniati, 2012). The guided inquiry module based on a research result is selected because it is one type of teaching material suitable for understanding and age levels and improves knowledge of theoretical review and daily life realities.

Recent studies related to this study include inquiry module in the Finland (Mamun, Lawrie, \& Wright, 2020; Thuneberg, Salmi, \& Bogner, 2018), and in the United States (Zhang, 2019). Research related to inquiry and science process in Turkey (Ekici \& Erdem, 2020). Research related to inquiry and cognitive learning outcomes in South Korea (Cho et al., 2017), and in United Kingdom (Kovanovic, Gasevic, Joksimovic, Hatala, \& Adesope, 2015). Research related to guided inquiry module in animal reproduction system content to improve student science process skills and cognitive learning outcome has yet to be done. Thus, the study's improved outlook is that no one has yet developed guided inquiry module in animal reproduction system content to improve student science process skills and cognitive learning outcome. This research contributes to the field of education. These contributions include being able to become a reference module for educators in teaching reproductive system material. Another gift is that this module is also a reference for educators to develop scientific process skills and student learning outcomes when studying reproductive system material.

According to the background, a guided inquiry module in animal reproduction system content will be developed. The developed module is based on researching the potential of single clove garlic (Allium sativum) extract on sperm quality of hyperlipidemia model of male mice to improve student science process skills and cognitive learning outcome. Development research aims to produce, test the validity, practicality, and 
effectiveness of guided inquiry modules on animal reproductive systems to improve student science process skills and cognitive learning outcomes.

\section{METHOD}

The research was development research using the ADDIE model that consisted of 5 (five) stages: analysis, design, development, implementation, and evaluation (Branch, 2009). The analysis phase serves to find out various problems and needs during the learning process. The analysis phase is carried out by observing learning activities, interviews, and the provision of needs analysis questionnaire. In the analysis, the stage also set development objectives to produce and test the guided inquiry module's validity and practicality based on research results. The module development target is the student offering A Biology Department, IKIP Budi Utomo Malang, which will be held from May 2018 to December 2018.

The design phase functions to design a guided inquiry module based on research results. At the design stage, a list of tasks to be designed in the guided inquiry module based on the research result, the display of the module objects, the validation questionnaire, and the practicality questionnaire (Qadariah, Lestari, \& Rohman, 2019).

The development phase serves to develop the module design result made at the design stage (Branch, 2009). Stage of development includes the design of content in the module, including research results, the potential of single clove garlic (Allium sativum) extract on sperm quality of hyperlipidemia model of male mice. At the development stage, also used supporting media in doing module and making instructions for using the module. The module that has been developed is tested for validity $b$ material experts, the media, and field practitioners. The material expert validator is Prof. Dr. Abdul Gofur, M.Si., and the media expert validator is Dr. Munzil, S.Pd., M.Si., validator od field practitioners namely Dwi Candra Setiawan, S.Si., S.Pd., M.Pd., and Nila Kartika Sari, S.Si, M.Si. Educational background and areas of expertise are the basis for selecting a guided inquiry module validator. After being declared valid by the module validator, it was tested on 15 offering A students majoring in Biology IKIP Budi Utomo Malang who were taking Animal Physiology courses to test the practicality of the module.

The implementation phase is carried out using guided inquiry modules in animal reproductive system material based on research results to improve science process skills and students' cognitive learning outcomes. Implementation of guided inquiry modules based on research results using a quasi-experimental design. The quasi-experimental research design chosen was the nonrandomized control group pretestposttest system (Leedy \& Ormrod, 2016). The research designs are approved in Table 1. Information (1) $\mathrm{O}_{1}=$ Pretest control class; (2) $\mathrm{O}_{2}=$ Posttest control class; (3) $\mathrm{O}_{3}=$ Pretest experiment class; (4) $\mathrm{O}_{4}=$ Postest experiment class; (5) $X_{1}=$ Learning without using modules; (6) $X_{2}=$ Learning by using modules.

Table 1. Research design nonrandomized control group pretest-posttest design

\begin{tabular}{lccc}
\hline Subject & Pretest & Treatment & Postest \\
\hline Control (-) & $\mathrm{O}_{1}$ & $\mathrm{X}_{1}$ & $\mathrm{O}_{2}$ \\
Experiment & $\mathrm{O}_{3}$ & $\mathrm{X}_{2}$ & $\mathrm{O}_{4}$ \\
\hline
\end{tabular}

The research population is students who are taking IKIP Budi Utomo Malang animal physiology course. The sampling technique used is simple random sampling because the cognitive abilities of students are considered homogeneous. The study was conducted in class $A$ as an experimental class (using the guided inquiry module based on the survey) as many as 40 students and class $B$ as a control class (conventional methods without modules) as many as 40 students.

The evaluation stage functions to find out the deficiencies in the module as a basis for module improvement. The evaluation phase is carried out at each stage of the previous ADDIE development (Branch, 2009). The research instruments for collecting data included a material expert validation sheet by one material expert validator, a media expert by one media expert, a field practitioner expert by two field practitioners expert validator, a practicality questionnaire module for 15 students, a pretest-posttest question sheet validated science process skills and cognitive learning outcomes.

The data analysis technique of guided inquiry module development research is quantitative and qualitative descriptions. Qualitative analysis is done by grouping information in the form of opinions, suggestions, and remedial comments from validators and students as practicality testing subjects. Quantitative data analysis for the validation questionnaire and practicality test uses the following Formula 1. 


$$
P(\text { percentage })=\frac{\sum \mathrm{X}(\text { the total score of respondents'answers })}{\Sigma \mathrm{Xi}(\text { the total sum total score })} \times 100 \%
$$

Percentage assessment data obtained were converted into descriptive quantitative data using the validity criteria shown in Table 2. This is intended to give meaning and make decisions about the quality of the product modules that are developed. Percentage assessment data obtained were converted into descriptive quantitative data using practical criteria shown in Table 3 . This is intended to give meaning and make decisions about the quality of the product modules that are developed.

\begin{tabular}{ccl}
\multicolumn{3}{c}{ Table 2. Research criteria data percentage of product validity } \\
\hline No. & Validity criteria (\%) & Level of validity \\
\hline 1. & $85.01-100.00$ & Very valid, or can be used \\
2. & $70.01-85.00$ & Valid enough, or can be used but needs a little revision \\
3. & $50.01 \%-70.00$ & Invalid, it is recommended not to use it because it needs a lot of revisions \\
4. & $01.00-50.00$ & Invalid, or may not be used \\
\hline
\end{tabular}

Table 3. Evaluation criteria for percentage of product practicality

\begin{tabular}{ccl}
\hline No. & Practical criteria (\%) & \multicolumn{1}{c}{ Practicality } \\
\hline 1. & $81.00-100.00$ & Very practical, or can already be used \\
2. & $61.00-80.00$ & Practical, or can be used but needs to be revised slightly \\
3. & $41.00-60.00$ & Less practical, it is recommended not to use because it needs a lot of revisions \\
4. & $21.00-40.00$ & Impractical or may not be used \\
5. & $00.00-20.00$ & Very impractical, may not be used \\
\hline
\end{tabular}

Data analysis of science process skills and cognitive learning outcomes using non-parametric analysis techniques, namely quad's rank analysis of covariance. Data analysis serves to test whether there are differences in the mean of bound variables between two groups by controlling other variables that affect the dependent variable.

\section{RESULTS AND DISCUSSION}

The development's end product was a guided inquiry module in animal reproduction system topics based on a research result. The module was a teaching material containing content unit made according to the learning achievement. The module guided planned learning that could be studied independently by students with or without teacher assistance. The module production's important components included content, student worksheet, question sheets, and critical answers (Mulyasa, 2006).

The module compiled had been through analysis, design, development, implementation, and evaluation stages (Branch, 2009). Questionnaire analysis of the needs of the reproductive system material for lecturers' shows learning is done through the method of presentation and discussion, learning resources in the form of scientific articles, and effectively improving students' understanding of concepts. The results of the needs analysis questionnaire for lecturers also showed that the learning process had never used a guided inquiry module based on the study results. In addition to giving questionnaires, an interview was conducted at the lecturer. Interviews show that learning resources in the form of modules and scientific articles as learning resources are not yet available in all materials, such as in the reproductive system. Therefore we need learning resources on the fabric of the reproductive system. Subject lecturers strongly agree if a guided inquiry module is developed based on research results. This is very good as an innovation in education to facilitate educators during the learning process. Research results can also be an essential part of understanding the reproductive system and are useful for providing the latest information for students (Parmin \& Peniati, 2012).

Learning is done by presentation and discussion ( $87.9 \%$ of students) is the result of a questionnaire analysis of students' needs. But the use of specific learning models to increase interest and motivation to learn is the advice given by students. As many as $60.6 \%$ of students have difficulty in understanding the reproductive system because the material is abstract and complicated (25\% students), concepts are understanding (20.8\% students), difficult to apply in real life (12.5\% students), and lack of availability of relevant teaching materials (37.5\% students). The method used to overcome difficulties in the reproductive system material is finding other learning resources, asking the lecturer, and discussing with friends in one 
class. In general, animal physiology learning has used various learning resources, but only limited to certain materials. During the learning process, $69.7 \%$ of students had never used a guided inquiry-based module, and $97 \%$ of students agreed to develop a guided inquiry module. The research objective is to produce a guided inquiry module based on research results on the reproductive system material for animal physiology courses that are valid, practical, and effective. The module will be implemented in Offering A Biology Department Student IKIP Budi Utomo Malang during animal physiology learning. The use of modules in the form of mold size B5. How to guide students in learning the reproductive system in modules through guided inquiry models. The result of the analysis stage can generally be inferred that a guided inquiry module in the reproduction system topic based on research results was needed to be developed to improve student science process skills and cognitive learning outcomes.

The design stage was conducted by planning all components to be loaded in the module. Once the design was completed, the module was developed. At the design stage, prototype guided inquiry module design including arranging objects in the module. The module developed was expected to become an alternative learning source that helped students understand the reproduction system content. The core part of the module contained learning activities. The guided inquiry module based on research results consisted of three learning activities: learning activity one on reproduction organs, learning activity two on reproduction physiology, and learning activity three on fertilization, pregnancy, and labor.

Each learning activity is complemented by the syntax of the inquiry model, namely the exploration of phenomena, focusing questions, planning investigations, conducting investigations, analyzing the results of studies, constructing new knowledge, and communicating knowledge (Llewellyn, 2013) designed in the form of student worksheets located at the beginning of each activity learn. The phenomenon loaded in each learning activity was the result of research conducted. The research results could provide a real learning experience for students (Parmin \& Peniati, 2012; Tasir \& Pin, 2012), improve students' understanding, and provide information about development and invention in content discussed. Besides, the research results were practice to be used in learning (Faot, Zubaidah, \& Kuswantoro, 2016), improved learning quality and had adaptability to science and technology (Mahfudhillah, Al-Muhdhar, \& Sueb, 2017). The research results were loaded in the module where the potential of single clove garlic (Allium sativum) extract on male mice sperm quality. The phenomenon of exploring phenomena serves to train the observing aspects of the science process skills (Llewellyn, 2013).

Students are asked to write questions based on the phenomenon that has been explored. This activity aims to improve thinking skills and curiosity in the syntax of focusing problems. The focus phase of the question trains aspects of asking questions of science process skills (Conn, Bohan, Pieperc, \& Musumeci, 2020; Gultepe, 2016). Next, students are asked to plan an investigation. The investigation was carried out following the items that were formulated (Llewellyn, 2013). Investigating the syntax was loaded in a laboratory practice method in sperm calculation, motility observation, and sperm morphological normality. Students are asked to determine the data to be collected to answer questions. The planning phase of the investigation trains aspects of formulating hypotheses and planning the investigation of science process skills.

The next activity analyzes the investigation results in the form of interpreting and interpreting data, looking for patterns and relationships between variables, modifying, and drawing initial conclusions. The purpose of analyzing the results of research is so that students can find answers to questions made. The stage of analyzing the results of an inquiry trains aspects of analyzing data from science process skills. The 6th syntax of student guided inquiry is asked to form new knowledge. Developing new knowledge is defined as new knowledge gained from the investigation results to answer the questions given. This activity aims to build a new understanding of students. The stages of forming unique knowledge train aspects of applying the concepts of science process skills. The syntax further communicates new knowledge. New knowledge is disseminated through explanations with oral reports, PPT, or other media needed. The purpose of this activity is for students to convey new knowledge gained. The stage of communicating unique knowledge trains aspects of communication in science process skills (Curtis, Brownlee, \& Spooner-Lane, 2020; Martin, Sigur, \& Schmidt, 2005).

Each learning activity was ended with a formative test. The productive test was equipped with a critical answer so that students could measure their understanding independently following the module characteristics. The formative test was an essay question. The essay question was used since it has a better information function value (Susongko, 2010). Students were provided with the freedom to express understanding. It was useful to measure the achievement level of cognitive learning outcomes. The module's end part consisted of a summative test and the critical answer, glossary, and reference. The summative test 
served to measure the overall student understanding of all content in the module. The dictionary helped students learn the definition of terms in the module and understand the concept being studied (Elfeky, Masadeh, \& Elbyaly, 2020; Faot et al., 2016; Post, Guo, Saab, \& Admiraal, 2019; Ucar \& Trundle, 2011).

The development phase includes designing content, developing supporting media, developing user manuals for students and lecturers, making formative revisions, and conducting preliminary trials (Branch, 2009). At the development stage, module validation is performed. The content expert, media expert, and field practitioner expert validated the developed inquiry module based on a research result. The validation was intended to determine the module's weaknesses and be used as a material for improvement and produce a module suitable to student needs.

The material expert validator is $\mathrm{Dr}$. Abdul Gofur, M.Si. The validator is a physiology lecturer at the Department of Biology FMIPA UM, who has a research background in reproductive systems. The material expert validator's validation results stated that the modules from aspects of content worthiness, presentation of content worthiness, and language worthiness were very valid and could be used in learning. The module's strength is that it can help understand the reproductive system and as additional teaching material in the teaching and learning process. Therefore the module can be used in learning with revisions (Akbar, 2013). The content expert's validation value category was 94.84 , with an excellent variety for all validation aspects. The module expert validation questionnaire consisted of three major components: the element of content eligibility, which included 12 points of evaluation, the feasibility of presenting content with 10 points of assessment, and language eligibility, which had 9 points of evaluation. A summary of the results of the material expert validation results can be seen in Table 4.

Table 4. Value of material expert validity

\begin{tabular}{llccccc}
\hline No. & \multicolumn{1}{c}{ Rated aspect } & $\begin{array}{c}\text { Number of } \\
\text { aspects }\end{array}$ & $\begin{array}{c}\text { Maximum } \\
\text { score }\end{array}$ & $\begin{array}{c}\text { Earnings } \\
\text { score }\end{array}$ & $\begin{array}{c}\text { Validity } \\
\text { value (\%) }\end{array}$ & Validity category \\
\hline 1. & Content eligibility & 12 & 60 & 57 & 95 & Very valid \\
2. & $\begin{array}{l}\text { Feasibility of content } \\
\text { presentation }\end{array}$ & 10 & 50 & 49 & 98 & Very valid \\
3. & $\begin{array}{l}\text { Language feasibility } \\
\text { Earnings score }\end{array}$ & 9 & 45 & 41 & 91.11 & Very valid \\
\hline
\end{tabular}

A product suitable for learning must be valid regarding its content feasibility, content presentation, and language feasibility aspects. Content loaded in the module must be correct, right, and thorough. The validation criteria of the content expert indicated the correctness of the content substance in the module. The media expert validator is Dr. Munzil, S.Pd., M.Si. The validator is a lecturer in education in the Department of Natural Sciences FMIPA UM. The validation results by the validator of the media experts stated that the modules from the aspects of graphics, presentation, linguistics, and modules have been very valid and can be used in learning. The module is suitable to be used as a learning resource. The advice given by the validator is to pay attention to the distance between paragraphs. Therefore the module can be used in learning with small revisions. A summary of the results of the validation of media experts can be seen in Table 5 .

Table 5. Value of media expert validity

\begin{tabular}{clccccc}
\hline No. & Rated sspect & $\begin{array}{c}\text { Number of } \\
\text { sspects }\end{array}$ & $\begin{array}{c}\text { Maximum } \\
\text { score }\end{array}$ & $\begin{array}{c}\text { Earnings } \\
\text { score }\end{array}$ & $\begin{array}{c}\text { Validity } \\
\text { value (\%) }\end{array}$ & Validity category \\
\hline 1. & Grapefruit & 10 & 50 & 44 & 88 & Very valid \\
2. & Presentation & 7 & 35 & 33 & 94.29 & Very valid \\
3. & Linguistic & 6 & 30 & 28 & 93.33 & Very valid \\
4. & Module & 14 & 70 & 66 & 94.29 & Very valid \\
\hline & Earnings score & $\mathbf{3 7}$ & $\mathbf{1 8 5}$ & $\mathbf{1 7 1}$ & $\mathbf{9 2 . 4 3}$ & Very valid \\
\hline
\end{tabular}

A good module had an attractive appearance with a combination of color, figure shape, and clear title. The module's language aspect must use an easy to understand language and the correct spelling (Akbar, 2013). Validator expert field practitioners, namely Dwi Candra Setiawan, S.Si., S.Pd., M.Pd. (validator 1) and Nila Kartika Sari, S.Si., M.Si. (validator 2). The validator is a lecturer in animal physiology courses at IKIP Budi Utomo Malang. The expert field validator's validation results stated that the modules from aspects of language feasibility, content eligibility, presentation feasibility, and guided inquiry were very valid. Field practitioner expert validator 1 gave some comments, the language used is good. Still, some writing needs to be improved. The content worthiness is excellent, but it needs to add the initial narrative to each sub-chapter to facilitate student understanding. The feasibility of presentation and guided inquiry is very good. Field practitioner expert 
validator 2 commented that the use of the language used was following EYD and the level of understanding of students' thinking. The material presented was feasible and pursued learning outcomes, but it would be better to add fertility period calculation material to the menstrual cycle. Therefore the module can be used in learning. A summary of the results of the field practitioner expert validation results can be seen in Table 6 .

Table 6. Validity value of field practitioner expert

\begin{tabular}{llccccc}
\hline No. & \multicolumn{1}{c}{ Rated aspect } & $\begin{array}{c}\text { Number of } \\
\text { aspects }\end{array}$ & $\begin{array}{c}\text { Maximum } \\
\text { score }\end{array}$ & $\begin{array}{c}\text { Earnings } \\
\text { score }\end{array}$ & $\begin{array}{c}\text { Validity } \\
\text { value (\%) }\end{array}$ & Validity category \\
\hline 1. & Language feasibility & 7 & 35 & 32 & 91.53 & Very valid \\
2. & Content eligibility & 5 & 25 & 24 & 96 & Very valid \\
3. & Feasibility of presentation & 10 & 50 & 48.5 & 97 & Very valid \\
4. & Guided inquiry & 8 & 40 & 39 & 97.5 & Very valid \\
\hline & Earnings score & $\mathbf{3 0}$ & $\mathbf{1 5 0}$ & $\mathbf{1 4 3 . 5}$ & $\mathbf{9 5 . 6 7}$ & Very valid \\
\hline
\end{tabular}

The development phase is carried out as a preliminary trial to determine the practicality of the module. The preliminary trial was conducted on 15 students who were taking IKIP Budi Utomo Malang animal physiology course. The preliminary trial category is divided into four aspects of assessment, including student interest, use, activeness, and evaluation. A summary of the results of practicality data analysis can be seen in Table 7 .

Table 7. Student response data on guided inquiry module

\begin{tabular}{llcc}
\hline No. & \multicolumn{1}{c}{ Rated aspect } & Score & Practicality category \\
\hline 1 & Attractive module display & 90.67 & Very practical \\
2 & Modules motivate to learn & 90.67 & Very practical \\
3 & Attractive module color choices & 89.33 & Very practical \\
4 & The material in the module is easy to understand & 86.67 & Very practical \\
5 & Modules can guide finding concepts & 88.00 & Very practical \\
6 & The material in the module relates to everyday life & 89.33 & Very practical \\
7 & Modules motivate to discuss & 97.33 & Very practical \\
8 & Modules help improve scientific thinking & 88.00 & Very practical \\
9 & Modules help independent learning & 97.33 & Very practical \\
10 & Modules make learning more effective & 88.00 & Very practical \\
11 & Modules increase learning activities & 92.00 & Very practical \\
12 & Practical modules are used in learning & 89.33 & Very practical \\
13 & Modules make learning not boring & 86.67 & Very practical \\
14 & Module languages are easy to understand & 92.00 & Very practical \\
15 & The letters used are easy to read & 96.00 & Very practical \\
16 & The picture presented clarifies the concept & 96.00 & Very practical \\
17 & Evaluations in modules can be a benchmark in & 94.67 & Very practical \\
& understanding the material od the animal reproductive & & \\
\hline smstem & & Very practical \\
\hline Validity value & 1164 & \\
\hline
\end{tabular}

A valid and practical module would be used in the learning process. The results of modules that have been valid and practical can be seen in Figure 1 dan Figure 2.

The implementation phase is carried out using guided inquiry modules on reproductive system material based on research to improve students' science process skills and cognitive learning outcomes in learning. The result of data analysis suggested that there was a significant difference between students who learned using the module and those who did not use the module. The guided inquiry module in animal reproduction system topics based on a research result was developed to improve student science process skills and cognitive learning outcomes.

The result of hypothesis testing using Quade's rank analysis of covariance suggested a difference in science process skills between students in the experimental class and control class. Hypothesis test results can be seen in Table 8. The learning outcome in the experimental class was significantly higher than the control class. It implied that the guided inquiry-based module in the reproduction system content based on a research result could improve students' science process skills. 


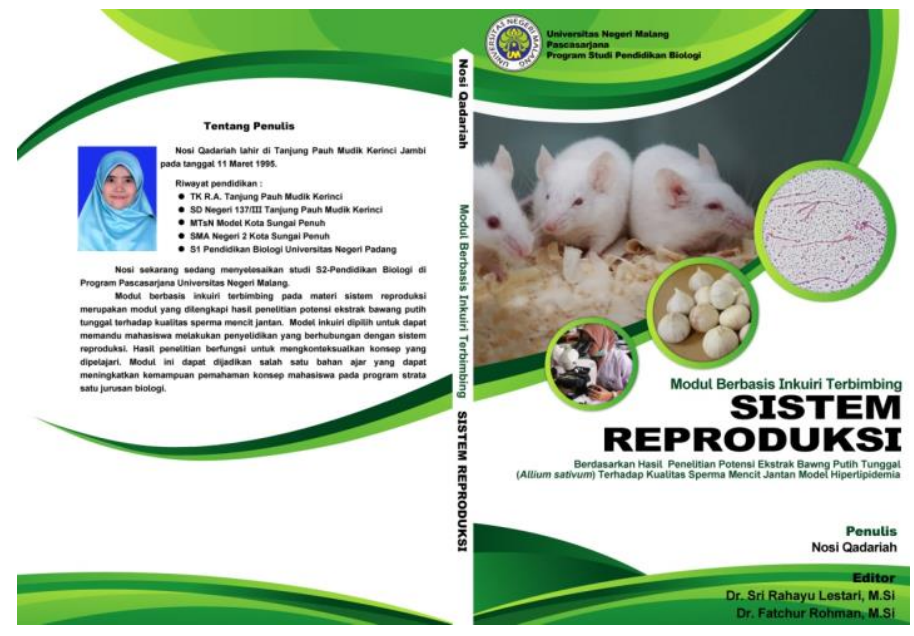

Figure 1. Front and back cover of the module

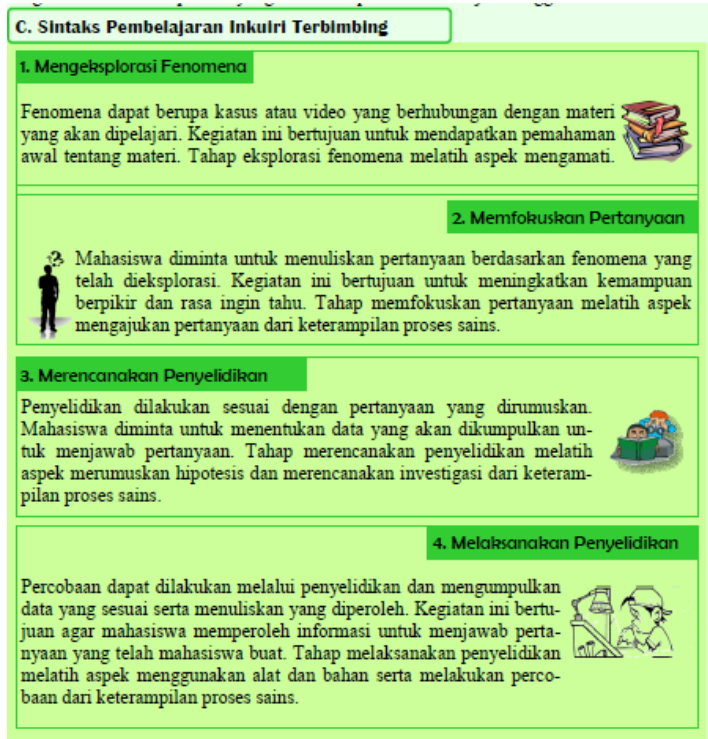

\begin{tabular}{|c|}
\hline 5. Menganalisis Hasil Penyelidikan \\
\hline $\begin{array}{l}\text { Kegiatan ini berupa menafsirkan dan memaknai data, mencari pola dan } \\
\text { hubungan antara variabel, memodifikasi, dan menggambarkan kesimpulan } \\
\text { awal. Tujuan menganalisis hasil penelitian yaitu agar mahasiswa dapat } \\
\text { menemukan jawaban atas pertanyaan yang dibuat. Tahap menganalisis ha- } \\
\text { sil penyelidikan melatih aspek menganalisis data dari keterampilan proses } \\
\text { saims. }\end{array}$ \\
\hline 6. Membentuk Pengetahuan Baru \\
\hline $\begin{array}{l}\text { Membentuk pengetahuan baru didefinisikan sebagai pengetahuran baru yang } \\
\text { didapatkan dari hasil penyelidikan untulk menjawab pertanyaan yang } \\
\text { diberikan. Kegiatan ini bertujuan untuk membangum pengetahuan baru } \\
\text { mahasiswa. Tahapan membentuk pengetahuan baru melatilh aspel } \\
\text { menerapkan konsep dari keterampilan proses sains. }\end{array}$ \\
\hline 7. Mengomunikasikan Pengetahuan Baru \\
\hline $\begin{array}{l}\text { Pengetahuan baru dikomunikasikan melalui penjelasan dengan laporan lisan, } \\
\text { PPT atau media lain yang dibutuhkan. Tujuan kegiatan ini adalah agar maha- } \\
\text { siswa mampu menyampaikan pengetahuan baru yang didapatkan. Tahap } \\
\text { mengkomunikaskan pengetahuan baru melatih aspek berkomunikasi dalam } \\
\text { keterampilan proses sains. }\end{array}$ \\
\hline
\end{tabular}

Figure 2. Guided inquiry learning syntax in modules

Table 8. Summary of final results of the quade's rank analysis of covariance science process skills

\begin{tabular}{lccccc}
\hline & Sum of squares & dF & Mean square & F & Sig. \\
\hline Between groups & 9098.994 & 1 & 9098.994 & 42.509 & .000 \\
Within groups & 16695.944 & 78 & 214.051 & & \\
\hline Total & $\mathbf{2 5 7 9 4 . 9 3 8}$ & $\mathbf{7 9}$ & & & \\
\hline
\end{tabular}

Students in the experimental class used an inquiry-based module based on a research result in the learning while learning in the control class was conventional using presentation and lecture methods. Efforts to improve science process skills in the module were trained through student worksheets that contained a guided inquiry model learning syntax. Student activities in the student worksheet were based on an inquiry syntax, namely: exploring the phenomenon, focusing questions, planning an investigation, conducting research, analyzing the investigation result, constructing new knowledge, and communicating the experience.

Each of the inquiry learning model stages trained a specific aspect of science process skills. The first syntax in the guided inquiry, exploring the phenomenon, trained the observing aspect. The second syntax, focusing on the phenomenon, trained the asking question aspect. The third syntax, planning an investigation, trained two aspects of the science process skills: planning an investigation and formulating a hypothesis. The fourth syntax, conducting research, trained two aspects of the science process skills: using tools and materials, and conducting an experiment. The fifth syntax, analyzing the investigation result, trained the data analysis aspect. The sixth syntax, constructing new knowledge, trained the implementing concept aspect. Last 
but not least, the seventh syntax, communicating the knowledge, trained the communicating aspect of the science process skill.

Stages in the inquiry learning model syntax have proven effective in improving science process skill aspects. There were differences in the value of each science process skill aspect measured. The average value of (1) observing aspect was 75; (2) asking question aspect was 79.4; (3) formulating hypothesis aspect was 90; (4) planning an investigation aspect was 60; (5) using tools and materials aspect was 87 ; (6) conducting an experiment aspect was 75.6; (7) analyzing data aspect was 71.2; (8) applying a concept aspect was 75 , and (9) communicating aspect was 97.5. Based on the values of the science process skill aspects, each syntax of the guided inquiry model was generally capable of improving students' science process skills. The syntaxes that had the most significant influence in improving students' science process skill included: (1) focusing questions syntax that trained to ask question aspect of the science process skill; (2) conducting investigating syntax that trains using tools and materials aspect, and (3) communicating syntax that trained to communicate an aspect of the science process skills.

The result of hypothesis testing using Quade's rank analysis of covariance indicated an influence on students' cognitive learning outcomes in the experimental and control classes. Hypothesis test results can be seen in Table 9.

Table 9. Summary of final results of the quade's rank analysis of covariance cognitive learning outcomes

\begin{tabular}{llccccc}
\hline & Model & Sum of squares & dF & Mean square & F & Sig. \\
\hline 1 & Regression & 3726.481 & 1 & 3726.481 & 7.480 & $.008^{b}$ \\
& Residual & 38858.519 & 78 & 498.186 & & \\
& Total & 42585.000 & 79 & & & \\
\hline
\end{tabular}

The learning outcome in the experimental class was significantly higher than in the control class. It suggested that the guided inquiry module based on a research result could improve student cognitive learning outcomes. Learning in the experimental class used an inquiry module based on a research result, whereas learning in the control class used a conventional way using presentation and lecture methods. They were learning using an inquiry module based on a research result guided students to have more experience than traditional learning. An inquiry model involves students to learn actively (Acar, 2014; Llewellyn, 2013; Warin, Kolski, \& Sagar, 2011). Efforts to improve the module's cognitive learning outcome were conducted through LKM, content description, and formative tests in each learning activity.

The inquiry learning model syntax loaded in the student worksheet was designed to facilitate the improvement of student cognitive learning outcomes. The exploring phenomenon and focusing question syntax facilitated cognitive level 2 (C2) or understanding. In both syntaxes, students were trained to construct an understanding related to reproduction system content. The syntaxes had proven to be able to improve students' cognitive level 2 (C2) value. The planning of an investigation syntax facilitated the improvement of cognitive level 4 (C4) or analysis. Conducting an investigation, constructing new knowledge, and communicating the knowledge syntax facilitated cognitive level 3 (C3) or applied. The analysis investigation result syntax facilitated the improvement of cognitive level 5 (C5) or evaluation.

Stages in the inquiry learning model syntax have proven effective in improving students' cognitive learning outcomes. There was a difference in value in each cognitive level measured. The average value of cognitive level 2 (C2) or understand was 75.4, the cognitive level 3 (C3), or applied was 73, the cognitive level 4 (C4) or analysis was 71.2, and the cognitive level 5 (C5) or evaluated was 70 . The average value of each cognitive level suggested that the higher the cognitive level measured, the lower the students' average value. The difference in each cognitive level value, however, was not significant. It can be inferred, thus, that learning using a guided inquiry-based module could improve the cognitive level of understanding (C2), apply (C3), analyze (C4) and evaluate (C5). The guided inquiry emphasized the investigation so that students could find new knowledge independently, and it could be an effort to improve student cognitive learning outcomes (Yuni Pantiwati, Permana, Kusniarti, \& Miharja, 2020; Uiterwijk-Luijk, Kruger, Zijlstra, \& Volman, 2019).

The improvement of students' cognitive learning outcomes is also related to improving students' science process skills. Students who learned using a guided inquiry-based module in the reproduction system content indicated improved science process skills and cognitive learning outcomes due to the developed module that was constructive (Kefi \& Uslu, 2015; Ozgelen, 2012; Pantiwati, Permana, \& Kusniarti, 2020). It provided many learning experiences to conduct an investigation and guided students to solve the phenomenon given. Students who had learning experience using a guided inquiry-based module in the reproduction system based on a research result improved their science process skills and cognitive learning outcome. 


\section{CONCLUSION}

A guided inquiry module based on a research result was very valid and practical. The content expert's validation result was $94.84 \%$, the media expert was $92.43 \%$, and the field practitioner expert was $95.7 \%$ with a very valid category. The result of module practicality was $91.3 \%$, with a category of very practical. There was a significant difference in the science process skills between students who learned using a guided inquiry module in the animal reproduction system based on a research result and those who did not use it. The module could improve students' science process skill with Fcalculate of 42,509 and $p$-value $=0.000<a(a=$ 0.05 ). There was a significant difference in the cognitive learning outcome between students who learned using a guided inquiry module in the animal reproduction system topic based on a research result and those who did not use the module. The module could improve students' cognitive learning outcome with Fcalculate of 7.480 and $p$-value $=0.008<\alpha(\alpha=0.05)$.

Suggestions that can be given for research related to this are observation sheet is a necessity to further assess the student science process skills, research is needed related to woman reproduction system so that it could become additional research results to be loaded in the module, an implementation is required to find out the influence of the module on related variables other than students' science process skill and cognitive learning outcome.

\section{ACKNOWLEDGMENT}

The research was a part of a research project by Dr. Sri Rahayu Lestari with decree 188/SP2H/LT/DRPM, the contract number 19.3.81/UN32.14.1/LT/2019. The researchers would like to send their gratitude to all research group members.

\section{REFERENCES}

Acar, O. (2014). Scientific reasoning, conceptual knowledge, \& achievement differences between prospective science teachers having a consistent misconception and those having a scientific conception in an argumentation-based guided inquiry course. Learning and Individual Differences, 30, 148-154. doi: https://doi.org/10.1016/j.lindif.2013.12.002

Akbar, S. (2013). Instrumen perangkat pembelajaran. Retrieved from https://rosda.co.id/pendidikankeguruan/378-instrumen-perangkat-pembelajaran.html\%0Ahttps://bit.ly/35ofYNZ\%0A

Bloom, B., Engelhart, M., Furst, E. J., Hill, W. H., \& Krathwohl, D. R. (1956). Taxonomy of educational objectives, the clasification of educational goal: handbook 1 cognitive domain. Retrieved from https://bit.ly/35hhvp1

Branch, R. M. (2009). Instructional design: the ADDIE approach. doi: https://doi.org/10.1007/978-0-38709506-6

Buck, G. A., Latta, M. A. M., \& Pelecky, D. L. (2007). Learning how to make inquiry into electricity and magnetism discernible to middle level teachers. Journal of Science Teacher Education, 18(3), 377-397. doi: https://doi.org/10.1007/s10972-007-9053-8

Cho, M.-H., Kim, Y., \& Choi, D. H. (2017). The effect of self-regulated learning on college students' perceptions of community of inquiry and affective outcomes in online learning. The Internet and Higher Education, 34, 10-17. doi: https://doi.org/10.1016/j.iheduc.2017.04.001

Conn, C. A., Bohan, K. J., Pieperc, S. L., \& Musumeci, M. (2020). Validity inquiry process: practical guidance for examining performance assessments and building a validity argument. Studies in Educational Evaluation, 65. doi: https://doi.org/10.1016/j.stueduc.2020.100843

Curtis, E., Brownlee, J., \& Spooner-Lane, R. (2020). Teaching perspectives of philosophical inquiry: changes to secondary teachers' understanding of student learning and pedagogical practices. Thinking Skills and Creativity, 38. doi: https://doi.org/10.1016/j.tsc.2020.100711

Donohoe, A. (2019). The blended reflective inquiry educators framework; origins, development and utilisation. Nurse Education in Practice, 38, 96-104. doi: https://doi.org/10.1016/j.nepr.2019.06.008

Ekici, M., \& Erdem, M. (2020). Developing science process skills through mobile scientific inquiry. Thinking Skills and Creativity, 36. doi: https://doi.org/10.1016/j.tsc.2020.100658 
Elfeky, A. I. M., Masadeh, T. S. Y., \& Elbyaly, M. Y. H. (2020). Advance organizers in flipped classroom via elearning management system and the promotion of integrated science process skills. Thinking Skills and Creativity, 35. doi: https://doi.org/10.1016/j.tsc.2019.100622

Faot, M. M., Zubaidah, S., \& Kuswantoro, H. (2016). Pengembangan modul teknik budidaya tanaman kedelai sebagai bahan ajar sekolah menengah kejuruan. Jurnal Pendidikan: Teori, Penelitian, \& Pengembangan, 1(7), 1421-1426. doi: https://doi.org/10.17977/jp.v1i7.6587

Graaf, J., Segers, E., \& Jong, T. (2020). Fostering integration of informational texts and virtual labs during inquiry-based learning. Contemporary Educational Psychology, 62. doi: https://doi.org/10.1016/j.cedpsy ch.2020.101890

Gultepe, N. (2016). High school science teachers' views on science process skills. International Journal of Environmental \& Science Education, 11(5), 779-800. doi: https://doi.org/10.12973/ijese.2016.348a

Kefi, S., \& Uslu, M. (2015). The effects of supportive scientific activities education program on pre-school teachers' usage levels of basic scientific process skills. Middle-East Journal of Scientific Research, 23(11), 2619-2626. doi: https://doi.org/10.5829/idosi.mejsr.2015.23.11.22389

Kovanovic, V., Gasevic, D., Joksimovic, S., Hatala, M., \& Adesope, O. (2015). Analytics of communities of inquiry: effects of learning technology use on cognitive presence in asynchronous online discussions. The Internet and Higher Education, 27, 74-89. doi: https://doi.org/10.1016/j.iheduc.2015.06.002

Leedy, P. D., \& Ormrod, J. E. (2016). Practical research: planning and design, 11th edition. Retrieved from https://pce-fet.com/common/library/books/51/2590_[Paul_D._Leedy,_Jeanne_Ellis_Ormrod]_Practical_ Res(b-ok.org).pdf

Llewellyn, D. J. (2013). Teaching high school science through inquiry and argumentation. Retrieved from https://books.google.co.id/books?id=bks4DQAAQBAJ\&lpg=PP1\&pg=PP1\#v=onepage\&q\&f=false

Mahfudhillah, H. T., Al-Muhdhar, M. H. I., \& Sueb, S. (2017). Pengembangan modul kawasan rumah pangan lestari (KRPL) berbasis proyek untuk siswa SMA. Jurnal Pendidikan: Teori, Penelitian, \& Pengembangan, 2(3), 400-408. doi: https://doi.org/10.17977/jptpp.v2i3.8655

Mamun, M. A. A., Lawrie, G., \& Wright, T. (2020). Instructional design of scaffolded online learning modules for self-directed and inquiry-based learning environments. Computers \& Education, 144. doi: https://doi. org/10.1016/j.compedu.2019.103695

Martin, D. J., Sigur, R. J., \& Schmidt, E. (2005). Process-oriented inquiry-a constructivist aproach to early childhood science education: teaching teacher to do science. Journal of Elementary Science Education, 17(2), 13-26. doi: https://doi.org/10.1007/BF03174678

Mulyasa, E. (2006). Kurikulum yang disempurnakan: pengembangan standar kompetensi dan kompetensi dasar. Retrieved from https://opac.perpusnas.go.id/DetailOpac.aspx?id=40139\#

Newton, X. A., \& Tonelli, E. P. (2020). Building undergraduate stem majors' capacity for delivering inquirybased mathematics and science lessons: an exploratory evaluation study. Studies in Educational Evaluation, 64. doi: https://doi.org/10.1016/j.stueduc.2019.100833

Ozgelen, S. (2012). Students' science process skills within a cognitive domain framework. Eurasia Journal of Mathematics, Science and Technology Education, 8(4), 283-292. doi: https://doi.org/10.12973/eurasia.2 $012.846 a$

Pambudiono, A., Suarsini, E., \& Amin, M. (2016). Pengembangan buku ajar bioteknologi berbasis penelitian bioremidiasi logam berat kadmium untuk mahasiswa s1 biologi universitas negeri malang. Jurnal Pendidikan: Teori, Penelitian, \& Pengembangan., 1(6), 1077-1085. doi: https://doi.org/10.17977/jp.v1i6. 6389

Pantiwati, Y., Permana, F. H., \& Kusniarti, T. (2020). The relationship between capability dimension and cognitive dimension ability of grade vii middle school students. The 3rd International Conference On Mathematics And Science Education (ICOMSE) 2019: Strengthening Mathematics and Science Education Research for the Challenge of Global Society. doi: https://doi.org/10.1063/5.0000556

Pantiwati, Y., Permana, F. H., Kusniarti, T., \& Miharja, F. J. (2020). The characteristics of literacy management in school literacy movement (SLM) at junior high school in malang - indonesia. Asian Social Science, 16(4). doi: https://doi.org/10.5539/ass.v16n4p15

Parmin, P., \& Peniati, E. (2012). Pengembangan modul mata kuliah strategi belajar mengajar IPA berbasis hasil penelitian pembelajaran. Jurnal Pendidikan IPA Indonesia (Indonesian Journal of Science Education), 1(1), 8-15. doi: https://doi.org/10.15294/jpii.v1i1.2006

Post, L. S., Guo, P., Saab, N., \& Admiraal, W. (2019). Effects of remote labs on cognitive, behavioral, and affective learning outcomes in higher education. Computers \& Education, 140. doi: https://doi.org/ 


\subsection{6/j.compedu.2019.103596}

Qadariah, N., Lestari, S. R., \& Rohman, F. (2019). Modul berbasis inkuiri terbimbing berdasarkan hasil penelitian pada materi sistem rerproduksi. Jurnal Pendidikan: Teori, Penelitian, Dan Pengembangan., 4(5), 634-639. doi: https://doi.org/10.17977/jptpp.v4i5.12426

Qadariah, N., Lestari, S. R., \& Rohman, F. (2020). Single bulb garlic (Allium sativum) extract improve sperm quality in hyperlipidemia male mice model. Jurnal Kedokteran Hewan, 14(1), 7-11. doi: https://doi.org /10.21157/j.ked.hewan.v14i1.13562

Seeley, R. R., Tate, P., \& Stephens, T. D. (2008). Anatomy \& physiology. Retrieved from https://trove.nla.gov.au/work/11441222/version/39028821

Susongko, P. (2010). Perbandingan keefektifan bentuk tes uraian dan teslet dengan penerapan graded response model (GRM). Jurnal Penelitian Dan Evaluasi Pendidikan, 14(2), 269-288. doi: https://doi.org/ 10.21831/pep.v14i2.1082

Tasir, Z., \& Pin, O. C. (2012). Trainee teachers' mental effort in learning spreadsheet through self-instructional module based on cognitive load theory. Computers \& Education, 59(2), 449-465. doi: https://doi.org/10.1016/j.compedu.2012.01.009

Thuneberg, H. M., Salmi, H. S., \& Bogner, F. X. (2018). How creativity, autonomy and visual reasoning contribute to cognitive learning in a STEAM hands-on inquiry-based math module. Thinking Skills and Creativity, 29, 153-160. doi: https://doi.org/10.1016/j.tsc.2018.07.003

Ucar, S., \& Trundle, K. C. (2011). Conducting guided inquiry in science classes using authentic, archived, web-based data. Computers \& Education, 57(2), 1571-1582. doi: https://doi.org/10.1016/j.compedu. 2011.02.007

Uiterwijk-Luijk, L., Kruger, M., Zijlstra, B., \& Volman, M. (2019). Teachers' role in stimulating students' inquiry habit of mind in primary schools. Teaching and Teacher Education, 86. doi: https://doi.org/10.1016 /j.tate.2019.102894

Warin, B., Kolski, C., \& Sagar, M. (2011). Framework for the evolution of acquiring knowledge modules to integrate the acquisition of high-level cognitive skills and professional competencies: principles and case studies. Computers \& Education, 57(2), 1595-1614. doi: https://doi.org/10.1016/j.compedu. 2011.02.013

Zhang, L. (2019). "Hands-on" plus "inquiry"? effects of withholding answers coupled with physical manipulations on students' learning of energy-related science concepts. Learning and Instruction, 60, 199-205. doi: https://doi.org/10.1016/j.learninstruc.2018.01.001 